\title{
Life cycle guideline of petrochemical plant underground piping system
}

\author{
Jeng-Ywan Shih ${ }^{1, a}$, Shen-Ying Hsiao ${ }^{2}$ and Ta-Peng Chang ${ }^{2}$ \\ ${ }^{1}$ Department of Chemical Engineering, Ming Chi University of Technology, New Taipei City 24301, Taiwan \\ ${ }^{2}$ Department of Civil and Construction Engineering, National Taiwan University of Science and Technology, \\ Taipei City 10607, Taiwan
}

\begin{abstract}
According to statistics of petrochemical plant disaster, the type of underground pipeline leakage is the highest proportion, for example, Kaohsiung gas explosion in 2014 is a typical case. Therefore, improvement strategy of petrochemical plant underground piping system from both engineering and management becomes an important issue. Through reviewing regulations as well as surveying questionnaire, including kinds of piping materials, 3D drawing files, operation procedures, information sharing, etc., the findings show lack contact of integrated management with engineering executive and insufficient technical requirements are major defects. Overviewing current problems of domestic petrochemical plant underground piping system management, and comparing to international criteria and specifications, this research focuses on the of piping design, construction, operations, maintenance, and inspection. Then management procedures and engineering technical feasibility strategies are suggested. In addition, the proposed life cycle guideline in order to reduce the disaster incidence of petrochemical plant underground pipelines.
\end{abstract}

\section{Introduction}

The petrochemical industry deriving oil refining industry, producing basic petrochemical raw materials including olefins, aromatic hydrocarbons, alkanes and so on. Furthermore, serial petrochemical products manufactured [1]. In Taiwan all petrochemical industry output value of about 3.4 trillion, up 12000 vendors, employment of about 28.5 million people [2]. The petrochemical industry is an important pillar of economy; however industrial disaster events often take place, major types mainly in the highest fire, followed by contact with harmful substances and explosion [3]. In 2012 continuously fire and explosion incidents of Mailiao industrial park, resulting in refineries, alkylation plants, and other related factories in full shutdown, although not causing deaths, but has caused a high degree of international media concern [4]. The survey found that the pipeline system problems account for a large proportion in the safety management of the petrochemical plant, the pipeline system has often been ignored, mainly due to the pipeline system through various parts of the whole plant, the management is more complex, and it is more likely to be negligent maintenance of disasters arising from leakage. July 31, 2014 in Kaohsiung gas explosion events have resulted in 32 deaths and 321 people were injured [5], and the loss of property is more difficult to estimate, even more clearly in petrochemical underground pipeline safety is already urgent. In response to the impact

\footnotetext{
${ }^{\text {a }}$ Corresponding author: jengywan@gmail.com
} 
of Kaohsiung gas explosion incident, the central and local governments to proceed with regulatory amendments, For example, Ministry of Economic Affairs in December, 2014 promulgated the "Underground pipelines Industrial Safety Management Reference Guide", July, 2015 Kaohsiung City Government set "Kaohsiung pipeline management and maintenance of existing industrial approach", etc. [6].

Petrochemical industry production of large-scale, operating more hazardous or harmful substances, and close production relationships between the various factories, in order to facilitate the storage and transportation of raw materials, mostly concentrated in the same area, with the process engineering control measures and the implementation of safety management procedures education and training, disaster prevention, prevention of accidents occurred outside, and industrial safety audit is focused on the monitoring and inspection process itself [7]. According to Chang's study, the proportion of petrochemical plant equipment damage to the pipeline system of the type accounted for $33 \%$ of the highest item, which is the main reason for corrosion of the pipeline [8]. For the petrochemical plant capable of safe operation, establishing proper pipeline system management system is a top priority should be the design, procurement, construction and operation of the petrochemical plant underground pipeline management mechanism and the corrosion protection and other engineering technology as key elements. From the various stages of the life cycle of underground pipelines petrochemical plant, selecting the appropriate underground pipeline management system and engineering technology, avoiding catastrophic event occurred in the past, making the total petrochemical plants underground piping system for safe use.

\section{Operation guideline and expert interview}

This study investigates the feasibility of establishing life cycle model of underground pipeline management system of technology and engineering, with reference to foreign petrochemical plant with safety criteria and domestic relevant regulations, drawing up underground pipelines petrochemical plant planning and design, construction, maintenance and inspection guideline, then conducting interviews with experts in industry, government and science, according to the draft amendment after recommendation and comparing Kaohsiung gas explosion incident crux, explaining the problem and proposing improvement strategy.

\subsection{Outline of guideline}

Outline of guideline is for petrochemical plant underground pipelines life cycle operation including plan, design, construction, maintenance, and inspection, the flowchart is shown in figure 1.

\subsubsection{Plan and design}

(1) Plan and design using Smart Plant (SP) software contains SP 3D (Three Dimension), SP PID (Piping and Instrument Diagram), SP I (Instrumentation) and SP M (Material) [9]. Smart Plant 3D graphics in 30\%, 60\%, $90 \%$ need to review SP 3D and SP PID correctness with the owners, and also in conjunction with the construction personnel audit constructability and maintainability. In addition, using geographic information system (GIS) to verify stratification and positioning of underground pipelines.

(2) Process flow diagram (PFD) is provided by licensor, then completing SP PID and SP I system in sequence, after considering safety, economy, operation, maintenance, constructability, environmental protection, and other factors, finishing the whole plant layout.

(3) While engineers perform design, calculation and graphics, complying with contract and specifications.

(4) Design calculations and analytical work are in accordance with the relevant design standards or comply with regulatory requirements. The use of software for design calculations should be tested 
and verified, using the qualified and legitimate software, and confirming that the adequate scope, content and limitations. Pipeline design calculations must be made stress calculations for review.

(5) Matching list of the pipeline and pipe fittings must be in accordance with the material, shape, size, connection, and other characteristics, especially welding, thread and flange engaging.

(6) According to API 580 risk-based inspection (RBI) [10], establishing a risk-based inspection program, selecting the location and the amount of inspection, in order to facilitate pipeline thickness measurement.

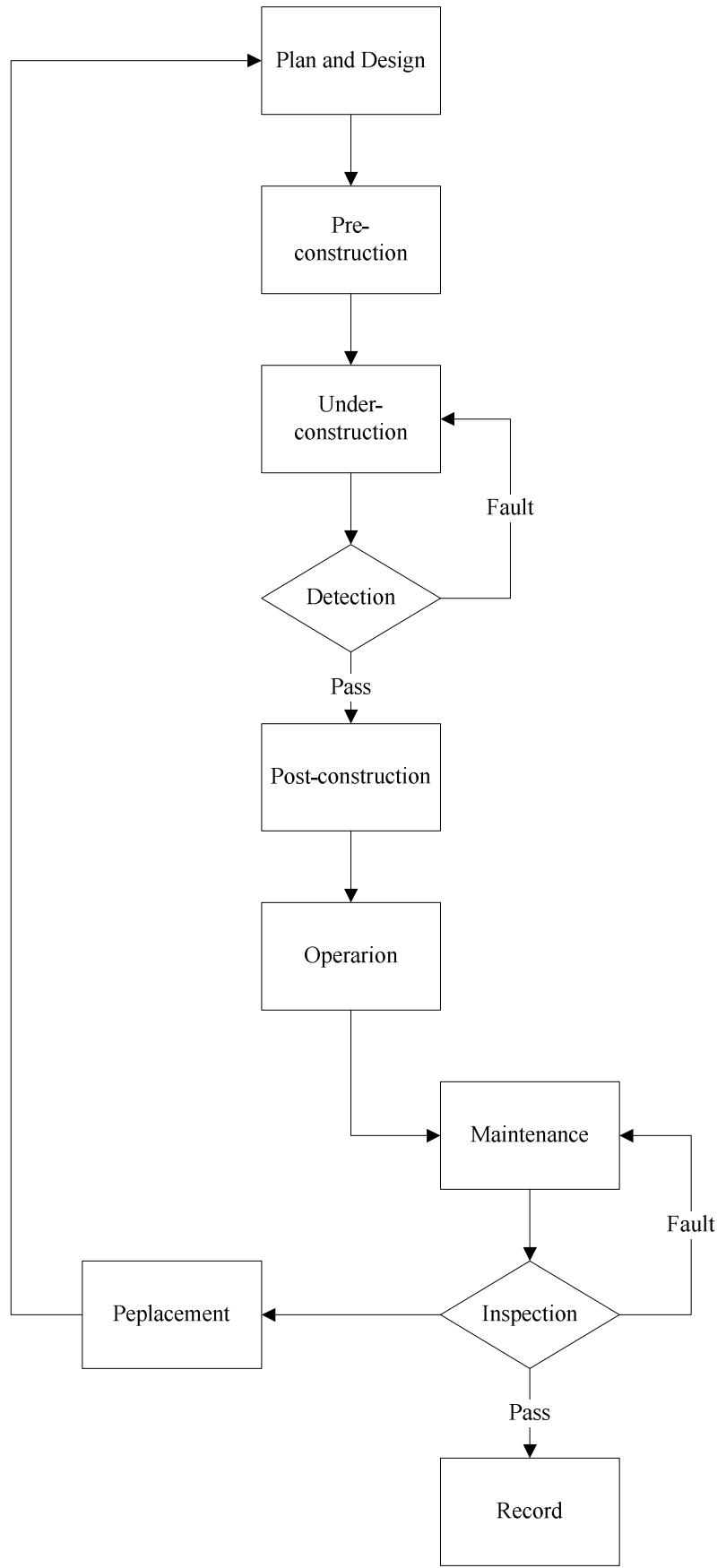

Figure 1. Flowchart of petrochemical plant underground pipelines life cycle operation process $[6,7]$ 


\subsubsection{Construction}

(1) Applying flare and operation permissions before construction, according to constructabilityoriented planning, arranging series schedule, reviewing the status of the pipeline material as well as related document.

(2) Underground Pipeline Construction jobs contain pipe and pipe fittings blasting, painting, coating, safety measures, trench excavation, prefabricated pipeline, pipeline lifting and welding, pipeline pressure test, establishing thickness database, cathodic protection, backfill and compaction.

(3) Underground pipeline construction subsequent job includes site clearance, built drawings, checklist, not only the implementation of self-inspections, but also in conjunction with the owners to examine and record full data, as a basis for acceptance.

\subsubsection{Maintenance}

Maintenance plan contains definitions exam type, such as an inner tube, an outer tube, operation and inspection; defined for each type of inspection and the execution time period; describing the inspection methods used for each type of inspection and non-destructive inspection techniques; description of test the location and status of non-destructive testing point condition; for the past inspection records describing those positions in the past there have been chipping record; taking once described the type of harm, to predict where may be damage in the future; describing the pipeline system possible type of defect, damage and injury rate acceptable standard; for a variety of types of defect, an appropriate description of non-destructive testing methods and testing capabilities; in accordance with relevant regulations and standards defined the maximum permissible during inspection; extending inspection requirements; according to the type of fluid, environmental damage and potential damage inspection adjustment period; description of requirement section of the pipe to check entry requirements and special tools.

(1) Operation requires Pay constantly attention to flow pressure of input and output ends output end, building a cloud platform for monitoring real-time information, if the abnormal situation happens, then taking emergency shutdown to avoid the damage.

(2) In order to obtain precise position and inspection of underground pipelines, so it had better use SP 3D and GIS for maintenance

(3) According to API 570 [11] of the pipeline system, performing thickness measurement and visual inspection, and the inspection cycle as shown in Table 1. Since climate of Taiwan is humid and rainy, considering environmental factor coefficient $(0.5-0.9)$ to adjust the inspection cycle, i.e. the least duration established by multiplying the environmental factor coefficients, reducing maintenance frequency, and increasing safety.

Table 1. Inspection cycle [11]

\begin{tabular}{|c|c|c|c|}
\hline Pipeline System & Thickness measurement & Visual inspection & $\begin{array}{c}\text { Environmental factor } \\
\text { coefficient }\end{array}$ \\
\hline Type 1 & 5 years & 5 years & $0.5-0.9$ \\
\hline Type 2 & 10 years & 5 years & $0.5-0.9$ \\
\hline Type 3 & 10 years & 10 years & $0.5-0.9$ \\
\hline Type 4 & $\begin{array}{c}\text { In accordance with the } \\
\text { actual needs }\end{array}$ & $\begin{array}{c}\text { In accordance with the } \\
\text { actual needs }\end{array}$ & - \\
\hline
\end{tabular}

Notes:

Type 1: A significant impact on the safety and environmental leakage, such as $\mathrm{C} 2, \mathrm{C} 3$ and $\mathrm{C} 4$ line.

Type 2: Other categories not included in the pipeline, such as hydrogen, fuel and gas pipelines.

Type 3: It is not located in densely populated areas, such as pipeline of tank storage area.

Type 4: Non-flammable and non-toxic pipeline, such as steam, nitrogen, lubricants and water lines. 


\subsubsection{Inspection}

Inspection contains pre-operation, inspection operation, inspection mode, etc. Items of cautions includes the relatively inaccessible underground pipeline set up radio frequency identification (RFID), confirming indeed visit of inspectors; using cameras equipped with GPS positioning at each checkpoint photos as evidence; for the same underground pipeline systems, each time different inspectors to avoid being deceived; every maintenance record must include the maintenance of underground pipeline photos; supervisors in charge of maintenance records shall sign off, if necessary checking part of the pipeline; the underground pipeline maintenance and replacement comply with contractual requirements.

\subsection{Issues of expert interview}

Table 2. Issues of expert interview for life cycle of petrochemical plant underground pipelines [9, 11]

\begin{tabular}{|c|c|}
\hline Life cycle stages & Issues \\
\hline \multirow{5}{*}{ Plan and design } & $\begin{array}{l}\text { Feasibility of underground pipelines unified design software using Smart Plant } \\
\text { with SP 3D. }\end{array}$ \\
\hline & $\begin{array}{l}\text { SP 3D graphics in } 30 \%, 60 \%, 90 \% \text { period required in conjunction with the } \\
\text { owners, reviewing the correctness, implementing constructability, checking the } \\
\text { adequacy and maintainability. }\end{array}$ \\
\hline & $\begin{array}{l}\text { Domestic regulations and standards are suitable for petrochemical plant } \\
\text { underground pipelines. }\end{array}$ \\
\hline & $\begin{array}{l}\text { For anti-corrosion coating type hot-melt, heat-resistant and cold-inclusive, which } \\
\text { is the most suitable for Taiwan environment? }\end{array}$ \\
\hline & Are there deficiencies for matching list contents of pipelines and pipe fittings? \\
\hline \multirow{6}{*}{ Construction } & Applying government permit before construction. \\
\hline & $\begin{array}{l}\text { The constructability oriented planning as well as scheduled construction } \\
\text { sequence within the plan stage shortens the construction duration and obtain } \\
\text { better quality. }\end{array}$ \\
\hline & $\begin{array}{l}\text { For pipes and pipe fittings material before installation must first blasting, using } \\
\text { double layers of epoxy primer painting, each a minimum of } 35 \mu \mathrm{m} \text {. }\end{array}$ \\
\hline & $\begin{array}{l}\text { Avoiding trench because rainwater from entering the tube section, the use of } \\
\text { impermeable plastic cover and tape to seal the nozzle orifice or at both ends of } \\
\text { the use of temporary closure welding. }\end{array}$ \\
\hline & $\begin{array}{l}\text { After completion of the construction site, the real size of the pipeline } \\
\text { immediately records in finished drawings, and updating SP 3D graphics and GIS } \\
\text { system. }\end{array}$ \\
\hline & Underground pipeline construction checklist is appropriate. \\
\hline \multirow{3}{*}{ Maintenance } & $\begin{array}{l}\text { Notice on operational flow pressures of input and output ends, with cloud } \\
\text { platform both sides can monitor real-time information each other. }\end{array}$ \\
\hline & $\begin{array}{l}\text { Considering Environmental factor coefficient from } 0.5 \text { to } 0.9 \text { for inspection } \\
\text { cycle. }\end{array}$ \\
\hline & Forcing owners and users of petrochemical pipelines to register. \\
\hline \multirow{4}{*}{ Inspection } & Detection methods are adequate for petrochemical plant underground pipelines. \\
\hline & Close interval potential detection executes proceeds every five years. \\
\hline & $\begin{array}{l}\text { Mandatory provisions of API 570-check / change / repair / deprecated standards } \\
\text { for petrochemical industry. }\end{array}$ \\
\hline & $\begin{array}{l}\text { Setting up RFID for the relatively inaccessible underground pipelines to confirm } \\
\text { indeed visit of inspectors, using cameras with GPS to position each checkpoint, } \\
\text { and introducing remote monitoring system to collect and control all information. }\end{array}$ \\
\hline
\end{tabular}

In accordance with petrochemical plants underground pipeline plan and design, construction, maintenance, and inspection, issues of expert interviews to develop the subject as shown in Table 2. Expert interviews via various petrochemical industry, related engineering companies, academia, government authorities and professional petrochemical plants underground pipeline inspection 
companies, namely 17 recommendations after finishing analysis, including plan and design 6, construction 2, maintenance 4 and inspection 5, amending life cycle guideline according to the proposed.

\section{Crux of the problem and improvement strategy}

Table 3. Crux of the problem and improvement strategy for life cycle of petrochemical plant underground pipelines operation process $[9,10]$

\begin{tabular}{|c|c|c|c|}
\hline $\begin{array}{c}\text { Life cycle } \\
\text { stages }\end{array}$ & Crux of the problem & $\begin{array}{c}\text { Kaohsiung gas } \\
\text { explosion incident }\end{array}$ & Improvement strategy \\
\hline $\begin{array}{c}\text { Plan and } \\
\text { design }\end{array}$ & $\begin{array}{l}\text { Domestic regulations } \\
\text { for underground } \\
\text { pipeline plan and } \\
\text { design, providing 3D } \\
\text { graphics and GIS } \\
\text { system are not } \\
\text { necessary. So, } \\
\text { inconsistencies arising } \\
\text { out of map data } \\
\text { happen. }\end{array}$ & $\begin{array}{l}\text { Serious problems of } \\
\text { graphic management } \\
\text { and lack of 3D } \\
\text { information of } \\
\text { underground pipeline. }\end{array}$ & $\begin{array}{l}\text { Smart Plant as the plan and } \\
\text { design software to facilitate } \\
\text { unified graphical format and } \\
\text { easy to integrate related } \\
\text { industry. Also the use of GIS } \\
\text { system with Smart Plant } \\
\text { software, obtaining accurate } \\
\text { position of underground } \\
\text { pipeline. Under the policy of } \\
\text { specific petrochemical zone, } \\
\text { building new underground } \\
\text { pipeline system as well as } \\
\text { migrating existing underground } \\
\text { pipeline to a common trench. }\end{array}$ \\
\hline Construction & $\begin{array}{l}\text { Domestic regulations } \\
\text { for underground } \\
\text { pipeline construction } \\
\text { without a unified } \\
\text { standard. Besides } \\
\text { introducing } \\
\text { international criteria, } \\
\text { it had better to } \\
\text { establish domestic } \\
\text { standards. }\end{array}$ & $\begin{array}{l}\text { At gas explosion site, } \\
\text { the 4-inch propylene } \\
\text { pipeline was enveloped } \\
\text { inside the drainage } \\
\text { culvert, not only the } \\
\text { patch was found, but } \\
\text { also any signs of } \\
\text { corrosion prevention } \\
\text { layers. }\end{array}$ & $\begin{array}{l}\text { Enforcing structure and material } \\
\text { inspection. Reviewing the } \\
\text { construction and quality report. } \\
\text { While underground pipeline } \\
\text { installation, using SP 3D } \\
\text { graphics, GIS system, and full } \\
\text { supervision. }\end{array}$ \\
\hline Maintenance & $\begin{array}{l}\text { Maintenance of } \\
\text { underground pipelines } \\
\text { inside plant is easier } \\
\text { than those outside } \\
\text { plant. Due to the } \\
\text { extensive area, it is } \\
\text { difficult to audit. } \\
\text { Furthermore, it rarely } \\
\text { excavating to } \\
\text { maintain, because } \\
\text { applying permission. }\end{array}$ & $\begin{array}{l}\text { After completion of the } \\
\text { pipeline, implementing } \\
\text { close interval potential } \\
\text { detection twice, first in } \\
\text { 1991, second in } 1997 . \\
\text { Propylene line belongs } \\
\text { to type } 1 \text { pipeline, } \\
\text { measuring the thickness } \\
\text { and making visual } \\
\text { inspection every five } \\
\text { years. Furthermore, lack } \\
\text { of input and output data } \\
\text { base. }\end{array}$ & $\begin{array}{l}\text { Establishing a cloud platform of } \\
\text { operation, showing real-time } \\
\text { information instantly. } \\
\text { Preparation of maintenance } \\
\text { plans, and according to } \\
\text { maintenance records, checking } \\
\text { with RFID in order to avoid } \\
\text { missing. The use of ultrasonic } \\
\text { gauge, measuring the thickness, } \\
\text { and then calculating the } \\
\text { remaining life of the pipeline. }\end{array}$ \\
\hline Inspection & $\begin{array}{l}\text { Kaohsiung road } \\
\text { excavation } \\
\text { management } \\
\text { regulations and } \\
\text { petroleum } \\
\text { management law are } \\
\text { no express provision. }\end{array}$ & $\begin{array}{l}\text { The completion of the } \\
\text { pipeline in 1991, } \\
\text { executing close interval } \\
\text { potential detection } \\
\text { twice. If only local } \\
\text { inspection, it is difficult } \\
\text { to detect. }\end{array}$ & $\begin{array}{l}\text { Firstly, applying SP 3D and } \\
\text { GIS system to verify the correct } \\
\text { position, and using smart pig to } \\
\text { check the inner and outer } \\
\text { thickness. Finally, performing } \\
\text { specific point thickness } \\
\text { inspection in accordance with } \\
\text { API 580. }\end{array}$ \\
\hline
\end{tabular}


Petrochemical plant operation problems are presented in life cycle stages of plan, design, construction; maintenance and inspection, with corresponding to Kaohsiung gas explosion incident, finally proposed improvement strategy are shown in Table 3.

\section{Conclusions}

(1) Life cycle guideline is practical for eliminating the disaster incidence of petrochemical plant underground pipelines.

(2) At the period $30 \%, 60 \%$, and $90 \%$ is the appropriate timing for the overall project, together with owners to review the correctness of $3 \mathrm{D}$ graphics.

(3) The constructability oriented planning as well as construction sequence schedule during plan stage not only shorten the construction period, but also obtaining better quality.

(4) All time pay attention to the flow pressure at input and output end on the operation, establishing a cloud platform for data base.

(5) For relatively inaccessible underground pipeline can be set up RFID, using cameras equipped with GPS positioning at each checkpoint photos as evidence to confirm the pipeline inspection, and introducing remote monitoring system for collecting and controlling all information.

(6) Close interval potential detection and cathodic protection belong to a wide range of protection; proceed every 5 years for low-risk pipeline, and 3 years for high-risk pipeline.

\section{References}

1. C.F. Lai and T.H. Chang, Win situation of environmental protection and economy, Science development, 455, 28-35 (2010)

2. Commerce, Industry and Services Census Report, Directorate General of Budget, Accounting and Statistics, Executive Yuan, ROC, 22-50 (2013)

3. C.W. Cheng and H.C. Yao, A study of occupational disaster survey and prevention in petrochemical industry of Taiwan, Industrial safety and health, 293, 43-63 (2013)

4. Z.S. Kao, C.Z. Chen, and C.M. Hsu, A study of hazard prevention for contractual operations in the petrochemical industry with one industrial park as case study, Journal of occupational safety and health, 19 (2), 319-329 (2011)

5. Disaster Management White Paper, Executive Yuan ROC, 40-45 (2015)

6. M.C. Dan, C.S. Li, and W.S. Li, The current status of underground pipeline safety management in Taiwan, Civil and Hydraulic Engineering, 43, 39-46 (2016)

7. C.M. Chang and C.T. Chen, The study of the grading and inspection system for safety management in petrochemical industry, Institute of Labor, Occupational Safety and Health, 5-8 (2015)

8. R.R. Chang, Study for remaining life estimation of localized and high temperature corrosion and inspection strategy for piping of refinery plant, Dissertation, National Yunlin University of Science and Technology (2004)

9. http://www.intergraph.com/products/ppm/smartplant/

10. API 580, Risk-Based Inspection, Second Edition, American Petroleum Institute (2009)

11. API 570, Piping Inspection Code In-service Inspection, Rating, Repair, and Alteration of Piping System, Third Edition, American Petroleum Institute (2009) 